\title{
TEMPORARY DYNAMICS OF WATER TEMPERATURE IN THE CARPATHIAN DAM RESERVOIR (BESKO IN THE UPPER VISTULA BASIN)
}

DOI: http://dx.doi.org/10.18509/GBP.2019.15

UDC: 556.51.08:536.22(438)

\section{Lukasz Wiejaczka}

Institute of Geography and Spatial Organization, Polish Academy of Sciences, Poland

\begin{abstract}
The study analyzes the temporal dynamics of water temperature in the vertical profile of the Besko reservoir located on the Wisłok river (upper Vistula river basin) in the Polish Carpathians. The data from 5-year water temperature monitoring were used in the analysis. Field surveys were conducted near dam of the reservoir (once a month) in the years 2014-2018. Measurements were carried out in the interval, every $1 \mathrm{~m}$ from the surface of water towards the bottom of the reservoir with using an electronic thermometer. The results of the studies showed that the Besko reservoir presents a typical for Carpathian dam reservoirs dynamics of thermal conditions during the year, strictly dependent on changes in thermal conditions of the air. Strong relations between water temperature and air temperature are gradually weakening along with the depth of the reservoir. During the summer, thermal stratification develops in the reservoir with vertical, several-degree temperature drop with a depth. The thermocline forms at smaller depths than in other large Carpathian reservoirs. In winter, reverse stratification is created in relation to the summer period, characterized by an increase of temperature values from the surface (covered with an ice) towards the bottom of the reservoir, and the difference in temperature values is $2-2.5^{\circ} \mathrm{C}$. In autumn and spring, transitional thermal conditions between summer and winter periods develop which exhibiting homothermia features. In addition, the state of homothermia in the reservoir is also observed in the case of so-called warm winters.
\end{abstract}

Keywords: water temperature, air temperature, Besko reservoir, Carpathians

\section{INTRODUCTION}

The dynamics of water thermal conditions in dam reservoirs have a fundamental impact on the course of hydrochemical processes and the development of biological life in water ecosystems of reservoirs [1]. Thermal conditions forming in the annual cycle in reservoirs also determine the thermal regime of rivers below their locations [2], [3], [4], and thus affect river ecosystems [5].

Thermal processes in natural lakes and dam reservoirs are shaped under the influence of external and internal factors, leading to the formation or disappearance of layers with different thermal characteristics in the mass of water. The temperature distribution in the reservoirs during the year is varied and conditioned by the dynamics of water mass being influenced by meteorological factors, i.e. air temperature, solar radiation, atmospheric precipitation, wind direction and speed causing water waving on the reservoir and by hydrological factors, i.e. quantitative and thermal variability of inflow and quantitative variability of water outflow from the reservoir resulting from the course of meteorological situations in a given year and from the method of water management in the reservoir [6]. 
In the Carpathians, studies of thermal conditions in dam reservoirs have been carried out to a limited extent so far, taking into account the number of examined objects and the scope of surveys carried out. Current knowledge about the formation of thermal conditions in dam reservoirs is based on the research of water temperature, performed mainly seasonally or irregularly. It allows to capture only the general trends of water temperature changes in the annual cycle. The detailed characteristic of the dynamics of thermal conditions in the reservoir requires the collection of long-term data from measurements made systematically in shorter time intervals.

The aim of the article is to present the temporal dynamics of water thermal conditions in the vertical profile of a mountain dam reservoir based on a long-term data set collected through systematic measurements (performed in a monthly time interval).

The Besko reservoir on the Wisłok river in the upper Vistula basin was selected for the studies (Fig. 1). The reservoir is located in the central part of the Polish Carpathians and is one of a dozen of large reservoirs functioning on the rivers in this area. The effect of the Besko reservoir on the thermal regime of the Wisłok river was the subject of considerations in the publications [4] and [7]. The creation of Besko reservoir in the upper course of the Wisłok river has resulted in small changes in the longitudinal thermal profile of the river. The reservoir affects the water temperature in a short section of the river, up to a maximum of 20 to $30 \mathrm{~km}$. The scale of the water temperatures changes in the Wisłok river is far smaller than observed in other Carpathian rivers downstream of larger reservoirs.

\section{STUDY AREA AND METHODS}

The Wisłok river is a left-bank tributary of the San river (the tributary of the Vistula river). The river regime, with rain, groundwater and snow feeding, is transitional between Western Carpathian rivers, characterised by summer floods as well as spring floods, and those of the Eastern Carpathians, which do not have a summer floods but a main flood in spring and a secondary in winter [8].

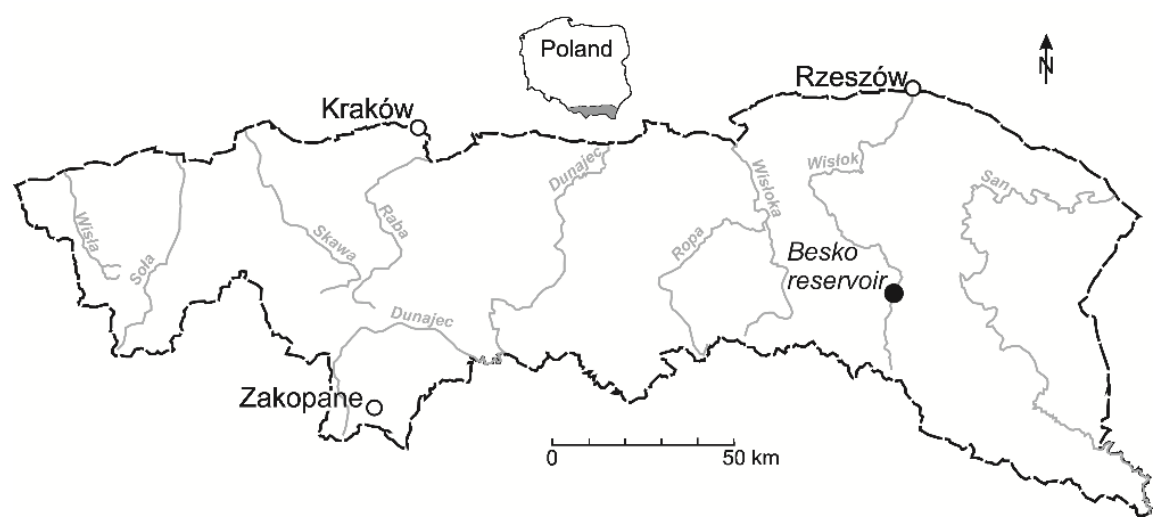

Figure 1. Localization of the Besko reservoir within the Polish Carpathians

The Besko reservoir dam is located at $183.9 \mathrm{~km}$ point of the Wisłok course. The total capacity of the reservoir is up to 15 million $\mathrm{m}^{3}$, its surface is $1.26 \mathrm{~km}^{2}$ at the maximum water level (336 $\mathrm{m}$ a.s.1.) and its maximum depth is $30 \mathrm{~m}$. The length of the reservoir is approx. $5 \mathrm{~km}$. The key purpose of creating the reservoir was to increase the minimum discharge of the Wisłok downstream from the dam. Flood protection is a secondary 
purpose. The guaranteed outflow from the reservoir, under normal operating conditions, is $0.9 \mathrm{~m}^{3} \cdot \mathrm{s}^{-1}$. The rate of water exchange for the Besko reservoir is 11 times per a year. Water temperature measurements were carried out in the vertical profile of the Besko reservoir located near dam (about the 15th of each month) in the hydrological years (from November to October) 2014-2018. The surveys were taken with an electronic thermometer with a plumb connected permanently to the measuring device with a 55metre long cable. The measurements were taken at intervals of 1 metre from the surface towards the bottom of the reservoir. The researches were conducted in the afternoon at maximum daily air temperature values.

\section{RESULTS AND DISCUSSION}

The analysis of the mean water temperature in the vertical profile of the Besko reservoir and the air temperature (recorded during the water temperature measurements) indicates that in the annual cycle, the temperature of the water stored in the reservoir follows the changes in the thermal conditions of the air (Fig. 2). The very high annual correlation of the mean water temperature in the Besko reservoir and air temperature (ranges in particular years from 0.91 to 0.97 ) is an evidence of close relations between the analyzed variables. According to [6] the daily temperature dynamics of the surface water layer in reservoirs shows an analogy to changes in air temperature, although the water temperature amplitudes are smaller. An extreme values of water temperature in the surface layer of the Carpathian reservoirs appear during the day 2-3 hours later than the extremes of air temperature. The biggest differences in the water temperature in a few meters surface layer of the reservoir are noticeable in the afternoon, and the smallest in the early morning hours.

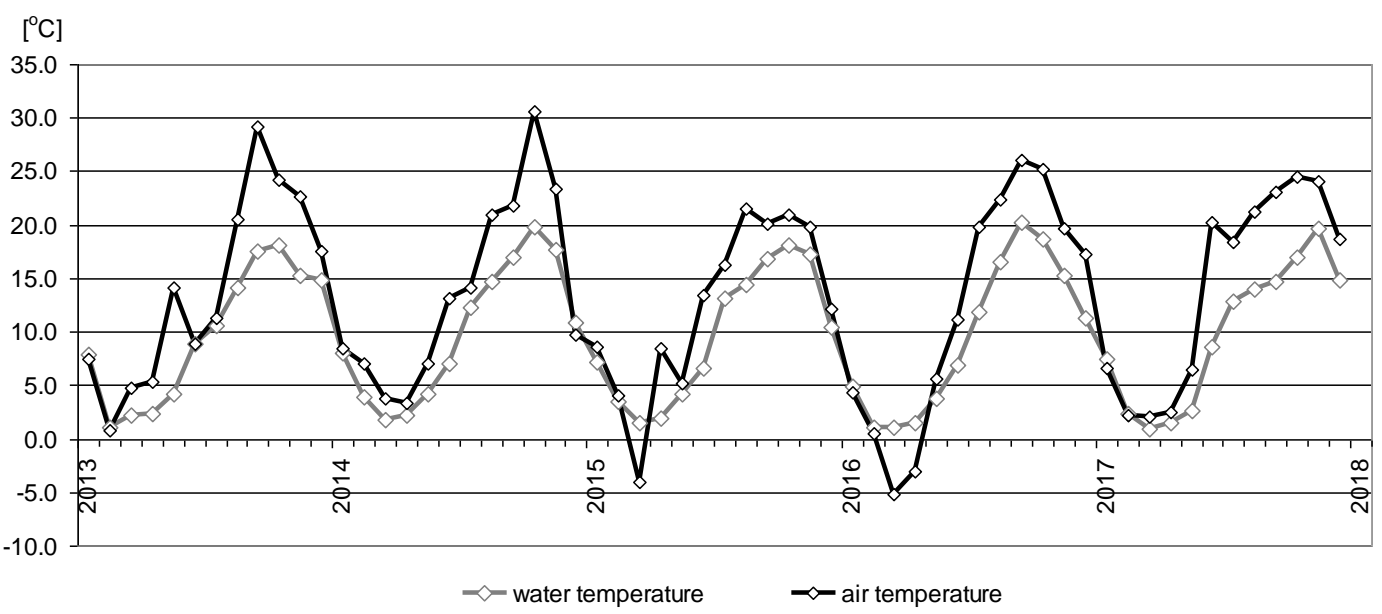

Figure 2. Dynamics of the mean monthly water temperature in the Besko reservoir in relation to air temperature in hydrological years 2014-2018

The deeper parts of the Besko reservoir react more slowly to changes in the thermal conditions of the air than the surface layer of the reservoir, which is characterized by the highest temperature amplitudes in the annual cycle. The values of the mean annual amplitude of the water temperature (for the period 2014-2018) in the layer up to a depth of $2 \mathrm{~m}$ from the water table are $21.1-23.7^{\circ} \mathrm{C}$, and in the layer up to $2 \mathrm{~m}$ from the reservoir's bottom are 8.9-14. $2^{\circ} \mathrm{C}$ (Fig. 3).

In the Besko reservoir during the summer (from April/May to September/October), is formed thermal stratifications typical for deep reservoirs of temperate climatic zone 
(dimictic) characterized by stagnation of warmer masses of water in surface and cooler masses in the bottom part of the reservoir (Tab. 1). The highest temperature drop reaching up to approx. $4.0^{\circ} \mathrm{C} / 1 \mathrm{~m}$ takes place at a depth of $1-2 \mathrm{~m}$. This indicates that the thermocline occurs at smaller depths than in other large Carpathian reservoirs where the epilimnion and hypolimnion separating layer was observed below $2 \mathrm{~m}$ (from 2-4 $\mathrm{m}$ to 5$6 \mathrm{~m}$ of the reservoir depth) [9]. This may results from the rapid rate of water exchange in the Besko relative to other reservoirs with a much larger capacity. In the winter period (January-February), with air temperature values below $0^{\circ} \mathrm{C}$, an ice cover up to approx. 30 $\mathrm{cm}$ thick is appeared on the Besko reservoir.

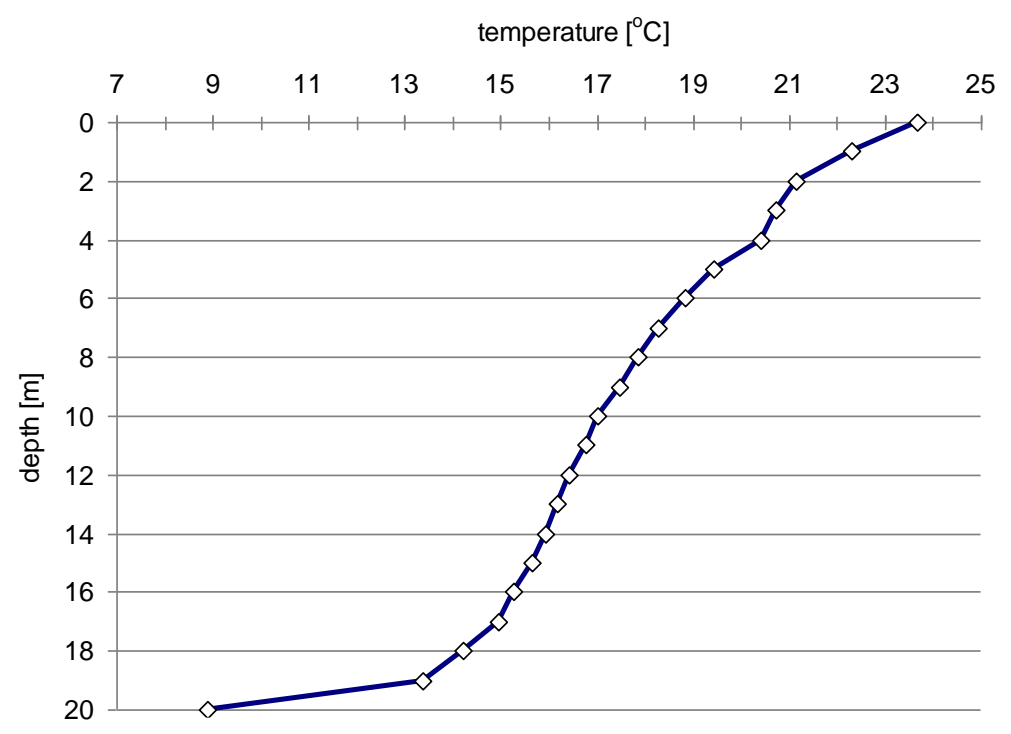

Figure 3. The mean annual amplitudes of water temperature in the vertical profile of the Besko reservoir (2014-2018)

The presence of the ice cover favors the formation of thermal stratification in the reservoir, which is reversed in relation to conditions during the summer period. With the depth, the temperature rises from approx. $0^{\circ} \mathrm{C}$ (under ice cover) to $2.0-2.5^{\circ} \mathrm{C}$ (within the bottom layer). In the so-called warm winters and lack of ice cover the temperature of the water in the entire vertical of the reservoir is close $\left(1.5-2.5^{\circ} \mathrm{C}\right.$ depending on meteorological conditions), and thermal conditions can be defined as a homothermic state similar to that observed in autumn (November-December) and spring (March), (Tab. 1). Appearance of homothermia in autumn and spring in reservoirs of Carpathian region is also confirmed by other studies [6], [9]. The analysis of the air temperature course for the considered area of the Polish Carpathians conducted by [10] shows the trend of an increase in the number of extremely warm months during a winter season in the last two decades. This may lead to a slow disappearance of winter thermal stratification formation in a deep dam reservoirs. 
Table 1. Mean monthly water temperature $\left({ }^{\circ} \mathrm{C}\right)$ in the Besko reservoir (2014-2018)

\begin{tabular}{|c|c|c|c|c|c|c|c|c|c|c|c|c|}
\hline Depth [m] & NOV & DEC & JAN & FEB & MAR & APR & MAY & JUN & JUL & AUG & SEP & OCT \\
\hline $\mathbf{0}$ & 7.7 & 2.3 & 1.1 & 1.6 & 4.0 & 9.9 & 18.0 & 21.1 & 23.9 & 22.6 & 18.7 & 13.4 \\
\hline $\mathbf{1}$ & 7.4 & 2.3 & 1.3 & 1.8 & 3.9 & 9.1 & 16.6 & 20.3 & 22.5 & 21.9 & 18.1 & 12.9 \\
\hline $\mathbf{2}$ & 7.4 & 2.3 & 1.5 & 1.9 & 3.8 & 8.9 & 15.4 & 19.9 & 21.4 & 21.6 & 17.7 & 12.8 \\
\hline $\mathbf{3}$ & 7.3 & 2.3 & 1.5 & 1.9 & 3.8 & 8.7 & 15.0 & 19.8 & 20.9 & 21.4 & 17.6 & 12.8 \\
\hline $\mathbf{4}$ & 7.3 & 2.4 & 1.5 & 1.9 & 3.8 & 8.6 & 13.9 & 19.2 & 20.3 & 21.3 & 17.5 & 12.8 \\
\hline $\mathbf{5}$ & 7.3 & 2.4 & 1.6 & 1.9 & 3.8 & 8.3 & 13.1 & 17.2 & 19.5 & 20.6 & 17.3 & 12.7 \\
\hline $\mathbf{6}$ & 7.3 & 2.4 & 1.6 & 1.9 & 3.8 & 7.8 & 12.6 & 16.0 & 18.4 & 20.1 & 17.3 & 12.6 \\
\hline $\mathbf{7}$ & 7.2 & 2.4 & 1.6 & 1.9 & 3.8 & 7.6 & 11.9 & 15.1 & 17.5 & 19.2 & 17.2 & 12.6 \\
\hline $\mathbf{8}$ & 7.2 & 2.4 & 1.7 & 2.0 & 3.8 & 7.5 & 11.6 & 14.4 & 17.1 & 18.7 & 17.1 & 12.5 \\
\hline $\mathbf{9}$ & 7.2 & 2.4 & 1.7 & 1.9 & 3.7 & 7.4 & 11.4 & 13.8 & 16.4 & 17.8 & 17.0 & 12.5 \\
\hline $\mathbf{1 0}$ & 7.2 & 2.3 & 1.8 & 2.0 & 3.8 & 7.4 & 11.2 & 13.3 & 15.8 & 17.1 & 16.9 & 12.5 \\
\hline $\mathbf{1 1}$ & 7.1 & 2.4 & 1.8 & 2.0 & 3.8 & 7.3 & 11.0 & 12.8 & 15.4 & 16.8 & 16.8 & 12.4 \\
\hline $\mathbf{1 2}$ & 6.9 & 2.4 & 1.9 & 2.1 & 3.8 & 7.1 & 10.8 & 12.3 & 15.3 & 16.6 & 16.6 & 12.3 \\
\hline $\mathbf{1 3}$ & 6.8 & 2.4 & 1.9 & 2.1 & 3.8 & 7.0 & 10.5 & 12.0 & 15.1 & 16.3 & 16.5 & 12.2 \\
\hline $\mathbf{1 4}$ & 6.9 & 2.4 & 1.9 & 2.1 & 3.8 & 6.9 & 10.5 & 11.9 & 15.0 & 16.1 & 16.3 & 12.1 \\
\hline $\mathbf{1 5}$ & 7.0 & 2.4 & 2.0 & 2.1 & 3.8 & 6.8 & 10.3 & 11.7 & 14.8 & 15.9 & 16.1 & 12.2 \\
\hline $\mathbf{1 6}$ & 6.6 & 2.4 & 2.0 & 2.1 & 3.8 & 6.8 & 10.3 & 11.5 & 14.6 & 15.5 & 16.4 & 12.4 \\
\hline $\mathbf{1 7}$ & 6.5 & 2.4 & 2.0 & 2.1 & 3.8 & 6.7 & 10.2 & 11.3 & 14.5 & 15.0 & 16.3 & 11.6 \\
\hline $\mathbf{1 8}$ & 6.4 & 2.5 & 2.0 & 2.2 & 3.7 & 6.7 & 10.1 & 11.2 & 14.2 & 14.9 & 16.0 & 11.5 \\
\hline $\mathbf{1 9}$ & 6.5 & 2.6 & 2.1 & 2.2 & 3.8 & 6.7 & 9.6 & 10.6 & 14.1 & 14.4 & 15.9 & 11.5 \\
\hline $\mathbf{2 0}$ & 7.1 & 2.7 & 2.3 & 2.5 & 3.7 & 6.5 & 9.3 & 10.9 & 13.5 & 16.2 & 14.7 & 10.6 \\
\hline & & & & & & & & & & & \\
\hline
\end{tabular}

\section{CONCLUSIONS}

The results of 5-year monitoring of water temperature in the vertical profile of the Besko reservoir allow to formulate the following conclusions:

- The Besko reservoir shows a typical for Carpathian reservoirs dynamics of the thermal conditions during the year, strictly dependent on changes of the air thermal conditions. Strong relations between water temperature and air temperature are gradually weakening along with the depth of the reservoir.

- In summer, thermal stratification develops with a vertical, several degree temperature drop with a depth. The thermocline forms at smaller depths than in other large Carpathian reservoirs. In winter, an inverse stratification is created in relation to the summer period, characterized by an increase in temperature of water from the surface (covered with an ice) towards the bottom of the reservoir and the difference in temperature values is $2-2.5^{\circ} \mathrm{C}$. In autumn and spring, transitional thermal conditions between the summer and winter periods are observed. These conditions very often demonstrate the homothermia features. The state of homothermia in the reservoir is also observed in the case of so-called warm winters.

The continuation of the water temperature measurements in the Besko reservoir in the next years will allow to collect a longer data series and thus for a more detailed recognition of the temporal dynamics of thermal conditions in the considered Carpathian reservoir.

\section{REFERENCES}

[1] Allan J. D., Castillo M. M. Stream ecology: structure and function of running waters, Springer Science and Business Media, Dordrecht, The Netherlands, 2007. 
[2] Soja R., Wiejaczka $Ł$. The impact of a reservoir on the physicochemical properties of water in a mountain river, Water and Environment Journal, vol. 28, no. 4, pp. 473-482, 2014.

[3] Wiejaczka Ł., Kijowska-Strugała M., Pierwoła P., Nowak M. Influence of the CzorsztynSromowce Wyżne reservoir complex on the Dunajec River thermal-regime, Geographia Polonica, vol. 88, no. 3, pp. 467-482, 2015.

[4] Wiejaczka Ł., Wesoły K. Effect of a small dam reservoir on the water temperature in a Carpathian river, Geographia Polonica, vol. 90, no. 4, pp. 481-491, 2017.

[5] Olden J. D., Naiman R. J. Incorporating thermal regimes into environmental flows assessments: modifying dam operations to restore freshwater ecosystem integrity. Freshwater Biology, vol. 55, no. 1, pp. 86-107, 2010.

[6] Cyberska B. Wpływ zbiornika retencyjnego na transformację naturalnego reżimu termicznego rzeki, Prace IMGW, vol 4, pp. 45-108, 1975.

[7] Kędra M., Wiejaczka Ł. Climatic and dam-induced impacts on river water temperature: Assessment and management implications, Science of The Total Environment, vol. 626, pp. 1474$1483,2018$.

[8] Dynowska I. Typy reżimów rzecznych w Polsce, Prace Geograficzne UJ, vol. 28, 1971.

[9] Wiejaczka Ł., Kijowska-Strugała M., Pierwoła P., Nowak M. Water temperature dynamics in a complex of reservoirs and its effect on the temperature patterns of a mountain river, Water Resources, vol. 45, no. 6, pp. 846-857, 2018.

[10] Bochenek W., Kijowska-Strugała M., Kiszka K. Long-term climatic trends in Szymbark (Poland), based on selected indicators, The Polish Geographical Review, vol. 90, no. 1, pp. 3552, 2018. 